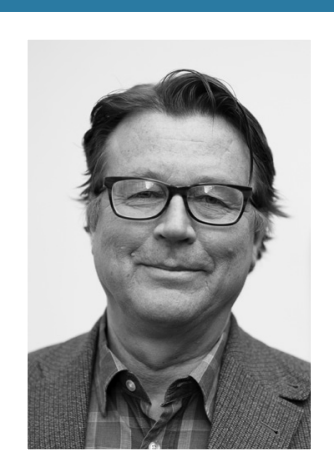

\title{
PÄÄKIRJOITUS
}

\section{TIEDE AUTORITAARISEN HALLINNON HAMPAISSA}

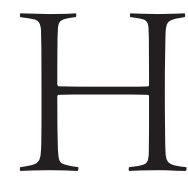

UHTIKUUN 22. PÄIVÄNÄ 2017 marssittiin tieteen puolesta sadoissa kaupungeissa eri puolilla maailmaa. March for Science-liike on syntynyt Yhdysvalloissa, jossa tiede ja politiikka tarjoilevat toisilleen vastakkaisia käsityksiä siitä, mikä on totta, mikä faktaa, mikä fiktiota. Tutkimustieto ja tutkijoiden näyttö esimerkiksi ilmastonmuutoksesta on kiistatonta.

Meillä ei ole parempaa tietoa kuin se, jonka tiede tuottaa. Mutta yhä useammin vallanpitäjät ja muut äänekkäät voivat kiistää tieteellisen tiedon oikeellisuuden asemansa perusteella tai "maalaisjärkeen" vedoten.

POPULISMI ELÄÄ yksinkertaistuksista ja ymmärtämättömyydestä. Faktat ja mielipiteet sekoittuvat. Aivan kuten omat mielipiteensä, jokaisen tulisi saada pitää omat faktansa. Nyt tieteentekijät ovat alkaneet havahtua tähän kyseenlaistamiseen. Helsingin yliopiston kosmologian professori Kari Enqvist kirjoitti YLEn kolumnissa 4. huhtikuuta, että erilaisiin kuvitelmiin on ollut tapana suhtautua lempeydellä:

"Jokaisella on oma tarinansa, postmodernit filosofit saarnasivat opettaessaan meitä suvaitsevaisiksi. Jokaisen tarina on samanarvoinen, he selittivät, ja media on ottanut tästä ilon irti julkaisemalla kritiikittä höpötarinoita vain myyntiään lisätäkseen. Mutta nyt suvaitsevaisuus saa riittää, sillä olemme nähneet mihin se johtaa. Tontut ovat palanneet takaisin ja johtavat kansakuntia Turkista Yhdysvaltoihin. [--] Nyt on tullut aika kaikkien kunnon kansalaisten astua esiin ja sanoa: totuudella on väliä. Totuus ei ole kauppatavaraa ja käsite 'vaihtoehtoinen totuus' on mieletön.”

SYYT SILLE, että tieteen ja tutkimustiedon asema yhteiskunnassa on viime vuosina ollut kasvavan huomion kohteena, ovat moninaiset.

Ensimmäinen syy on, että monet tutkimustulokset sopivat huonosti nykyiseen länsimaiseen elämäntapaan. Tiede on paljastanut ihmislajin kovaa vauhtia tuhoavan elämän edellytyksiä asuinplaneetaltaan, eikä vain muilta lajeilta vaan myös itseltään. Se on yksi niitä epämiellyttäviä totuuksia, joita populistiset poliitikot ja populistipuolueet ovat ryhtyneet joukolla kyseenalaistamaan. Populistiset puolueet hyötyvät ihmisten ahdingosta. Populistiset yksinkertaistukset lakaisevat monimutkaiset tieteelliset selitykset maton alle.

Internetin ansiosta epämiellyttävien tosiasioiden kieltäminen, denialismi, voi hyvin. Verkossa kaikki 


\section{FAKTOISTA EI P̈̈̈̈TET}

DEMOKRAATTISESTI.

saavat huutaa tasavertaisina kuuluville oman yksinkertaisen käsityksensä asioiden tilasta. Monimutkaisia selityksiä ja yhteyksiä nimittäin ei oikein huutamalla saa selviksi. Netissä kaikkien äänet ovat yhtä painavia ja yhtä hyviä - riippumatta siitä, ovatko ne mielipiteitä vai faktoja. Vain yksinkertainen on uskottavaa.

TOINEN SYY on talouskeskeinen ajattelutapa. Talouskasvu on korkein arvo, eikä sen kiihdyttämistä arvostelevia näkemyksiä suvaita, vaikka ne perustuisivat tutkimustuloksiin ja tieteellisiin faktoihin.

Tiede ei saisi häiritä bisnestä -ajattelu on tuttua aiemmilta vuosikymmeniltä. Mutta nyt 2010-luvulla ajatellaan yhä vahvemmin, että tieteen tulee nimenomaan palvella bisnestä. Aiempaa enemmän keskustellaan siitä, minkä verran humanistisia aloja kannattaa elättää yliopistoissa, ellei tutkimustuloksia saada tuotteistettua markkinoille ja vientiin.

Pääministeri Jyrki Kataisen (kok.) kaudella hallitus otti käyttöön hyötytutkimuksen käsitteen. Välitöntä taloudellista hyötyä tuottava, hallituksen päätöksiä tukeva ja legitimoiva tutkimus sai hyötytutkimuksen arvon. Näin se erottautui kaikesta hyödyttömästä tutkimuksesta, jonka parissa varsinkin humanistisissa tiedekunnissa näprätään. Maailmalla on esimerkkejä siitä, miten humanististen tieteiden kyseenalaistaminen etenee kokonaisten tiedekuntien lakkauttamiseen.

KOLMAS SYY tieteen ja sen autonomian kyseenlaistamiseen on autoritaarisen politiikan nousu.
Turkki, Unkari, Puola, Venäjä ja Yhdysvallat ovat suunnannäyttäjiä. Mutta ei autoritaarisuus ole outoa meilläkään. Pääministeri Juha Sipilä (kesk.) menettää malttinsa, kun "kaiken maailman dosentit" kyseenalaistavat hallituksen tavoitteiden ja keinojen yhteensopivuuden. Kun perustuslakioikeuden professorit epäilevät lakiesitystä perustuslain vastaiseksi, hallituksen piiristä heidän analyysinsa kyseenalaistetaan. Tutkijat leimataan "perustuslakifundamentalisteiksi”.

Autoritaarisuus yhdistyy yhä useammin vallitsevaan talousajatteluun. Kohta tieteenaloja, tutkimuslaitoksia ja tutkijoita asetetaan paremmuusjärjestykseen niiden taloudellisen ja poliittisen hyödyllisyyden mukaan.

KUN POLITIIKAN TEOSSA ideologia ja tieto joutuvat vastakkain, näyttää yhä useammin siltä, että tieto saa taipua. Tieteellisen tiedon hylkääminen ja vaihtoehtoisten faktojen, keksittyjen totuuksien levittäminen tietona on tyypillistä autoritaariselle hallinnolle.

Tieteellä on faktoja arvioitaessa ehdoton auktoriteetti. Faktoista ei päätetä demokraattisesti. Sen paremmin tieteentekijä kuin tiede instituutiona ei voi myöskään mukautua autoritaarisen hallinnon pyrkimyksiin menettämättä tieteellistä auktoriteettiaan.

Viime aikojen opetus on se, että tieteentekijän tulee aina epäillä vallassa olevia.

Heikki Silvennoinen 